[VOL. XX, NO.3

\title{
BRIDGELAND-RIVERSIDE COMMUNITY ASSOCIATION v. THE COUNCIL OF THE CITY OF CALGARY AND PATRICIA INVESTMENTS LTD.
}

\author{
DAVID PHILLIP JONES*
}

This decision ${ }^{1}$ of the Court of Appeal of Alberta deals with two important points, one related to planning law, and the other to administrative law generally. The first issue involves the relationship between an Area Redevelopment Plan and the Land Use By-Law enacted under The Planning Act, and the power of the Development Appeal Board to waive the requirements of either document. The second issue involves the effect of the Board's failure to re-notify interested parties after the amendment of the application to the Board, and in particular whether such a procedural error renders its decision void or merely voidable.

\section{FACTS}

The case arose out of the following facts. In 1980, Patricia Investments Ltd. applied for a permit to build an apartment in the BridgelandRiverside district. The application was rejected by the Development Officer because it did not comply with the use prescribed by the Calgary Land Use By-Law. On appeal to the Development Appeal Board, the applicant sought relief from the Land Use By-Law pursuant to section 85(3)(c) of The Planning Act, which provides as follows: ${ }^{3}$

85(3) In determining an appeal, the development appeal board . . .

(a) shall comply with any regional plan, ministerial regional plan, statutory plan and, subject to clause (c), any land use by-law or land use regulations in effect;

(c) may make an order or decision or issue or confirm the issue of a development permit notwithstanding that the proposed development does not comply with the land use by-law or land use regulations if, in its opinion.

(i) the proposed development would not

(a) unduly interfere with the amenities of the neighbourhood, or

(b) materially interfere with or affect the use, enjoyment or value of neighbouring properties,

and

(ii) the proposed development conforms with the use prescribed for that land or building in the land use by-law or land use regulations, as the case may be.

In fact, an Area Redevelopment Plan ${ }^{4}$ had been adopted by City Council for the Bridgeland-Riverside area, and the Land Use By-law in question had been amended to conform to the statutory plan.

* Of the Faculty of Law at The University of Alberta.

1. (1982) 19 Alta. L.R. (2d) 361.

2. The decision refers throughout to The Planning Act, 1977, although it has now been consolidated into R.S.A. 1980, c. P.9. None of the relevant provisions has been changed in the consolidation, but the sections of the Act have been renumbered. For convenience, this comment refers to the section numbers in the consolidated Act, and not to the old section numbers used by the Court. New section 85 was old section 83 .

3. Id. Emphasis added.

4. An area redevelopment plan is specifically included in the definition of a "statutory plan" contained in s. 1(u.1) of the Act. 


\section{THE PLANNING ISSUE: WHAT GOOD IS AN AREA REDEVELOPMENT PLAN?}

The issue in this part of the case can be stated very simply. Can the Development Appeal Board exercise its relieving power under paragraph 85(3)(c) to approve a development which does not meet the Land Use By-law, without thereby breaching the Board's obligation under paragraph 85(3)(a) to "comply with any ... statutory plan ..."? The clear wording of paragraph 85(3)(a) limits the Board's relieving power under paragraph (c) to permit deviations from land use by-laws or regulations only, and does not permit deviations from statutory plans. In other words, paragraph 85(3)(a) appears to set out a hierarchy of planning instruments, and permits the Board to alter only the two lowest types of documents: namely, land use by-laws or regulations. In particular, nothing in paragraph 85(3)(a) appears to authorize the Board to waive any provision of a statutory plan.

Section 67 of The Planning Act ${ }^{5}$ requires an area redevelopment plan to "conform with any land use by-law and any other statutory plan affecting the area...." In this case, the City simultaneously amended the land use by-law to conform to the new area redevelopment plan which it was implementing for this community. Accordingly, the provisions of paragraph 67 were complied with in this case, and it is not necessary to deal here with the consequences of a failure to alter the land use by-law to conform to a new area redevelopment plan.

The policy of paragraph 67 is clear: there should be no conflict between the terms of a statutory plan and the land use by-law which governs the land covered by the plan. One can ask, however, if that policy is achieved by the court's judgment in this case. Under the statute, the Board has been given power to amend a land use by-law ${ }^{6}$, but it has no power to amend an area redevelopment plan or any other statutory plan. An exercise, therefore, of the Board's dispensing power may well create nonconformity between the plan and the land use by-law. Unfortunately, the Court of Appeal does not appear to have considered this possible consequence of their judgment.

In any event, this case contradicts the general view previously held that an area redevelopment plan (or any statutory plan) takes precedence over a land use by-law, and that the existence of such a plan obliterates the Board's discretion under paragraph 85(3)(c) to vary the by-law which must reflect the plan. As Kerans J. said: ${ }^{7}$

... the special powers granted in [s. 85(3/(c)] to relieve from the strict terms of the Land Use By-law are an aspect of the scheme of implementaton [of plans] which survives the enactment of any Plan. In other words, nothing in Part 3 /of the Act, dealing with area redevelopment plans] authorizes a local government to sterilize the special powers of a development appeal board [to vary a land use by-law].

However, it would be wrong to assume that the Court of Appeal has now given development appeal boards the right to ignore the provisions of such plans altogether. As Kerans J. specifically said: ${ }^{8}$

... the Development Appeal Board can[not] ignore a Plan; on the contrary, it is bound to comply with it. An area redevelopment plan can and likely will narrow the scope of the classification in the

5. Formeriy s. 65 .

6. See s. $85(3)(\mathrm{c})$.

7. Supra n. 1 at 366.

8. Id. 
Land Use By-Law. A Plan limits the power of a Development Appeal Board; it does not, however, eliminate the narrow saving power contained in section [85(3)(c)].

Let us, therefore, re-examine the "narrow saving power" retained by the Boards. Again, paragraph 85(3)(c) says that a Development Appeal Board $^{9}$

may ... issue ... a development permit notwithstanding that the proposed development does not comply with the land use by-law... if, in its opinion,

(i) the proposed development would not

(a) unduly interfere with the amenities of the neighbourhood, or

(b) materially interfere with or affect the use, enjoyment or value of neighbouring properties,

and

(ii) the proposed development conforms with the use prescribed for that land or building in the land use by-law...

Clearly, the Board's dispensing power is restricted by clause (ii) so that the proposed development must conform with the "use prescribed" under the land use by-law. The Board cannot amend the land use by-law to change the use prescribed therein for the land (or building) on which the proposed development is to go; at most, the Board can only dispense with other requirement of the land use by-law. For example, assume that a plan clearly designates a particular lot to be used exclusively for residential purposes. The Board obviously cannot exercise its dispensing power under paragraph 85(3)(c) to permit a different use - such as a proposed commercial development - on that land, because the commercial use would not be the same as the residential use prescribed by the land use bylaw.

On the other hand, if the land use by-law requires the building to be set back twenty feet from the street, clearly the Board could exercise its dispensing power under paragraph 85(3)(iii) to waive this requirement, because no change in use is involved. Indeed, a large part of a land use bylaw may be directed to "other" matters unrelated to the use prescribed for the land: e.g., the area, size, height and location of buildings; ${ }^{10}$ the minimum size of lots; ${ }^{11}$ requirements for open space; ${ }^{12}$ landscaping; $;^{13}$ fences and walls; $;{ }^{14}$ parking $;{ }^{15}$ lighting $;{ }^{16}$ signs $;{ }^{17}$ and density of population.$^{18}$ If there is no statutory plan in place, the Board clearly has power under paragraph 85(3)(c) to waive any of these "other" requirements contained in the land use by-law.

Two complications must now be considered. First, what constitutes a "use" that is beyond the Board's power to alter? And second, if a statutory plan specifically deals with these "other" matters, can the Board still exercise its dispensing power under paragraph $85(3)$ (c) with respect to those "other" matters?

9. Supra n. 2. Emphasis added.

10. S. 69(3)(b).

11. S. 69(3)(a).

12. S. $69(3)(\mathrm{c})$.

13. S. $69(3)(d)$.

14. S. 69(3)(e).

15. S. $69(3)(f)$.

16. S. 69 (3)(i).

17. $\mathrm{S} .69(3)(\mathrm{m})$.

18. S. 69(3)(o). 
What, then, constitutes a "use"? The word is not defined in The Planning Act. Under paragraph 68(1), all municipalities with a population over 1,000 are obligated to enact a land use by-law. Under paragraph $69(2)(a)$, the by-law is to divide the municipality into as many districts of whatever size that the council considers appropriate. Sections $69(2)(b)$ and 71(1) require the council to prescribe the permitted and/or discretionary "uses" of land and buildings in each respective district. ${ }^{19}$ Nowhere, however, does the Act define what constitutes a "use". Nor did the Court of Appeal consider this question in the Bridgeland-Riverside case. On the contrary, their Lordships appear simply to have assumed that the proposed 123-unit apartment building complied with one of the "uses" comprised in the C2 commercial classification under the Calgary Land Use By-law.$^{20}$ If it did not, what lawful authority did the Development Appeal Board have under paragraph $85(3)$ (c) to waive the requirement of the by-law? Whether a proposed "use" is enumerated in the list of permitted or discretionary "uses" for a particular property in the land use by-law is a question of law and thus for the Court of Appeal to determine. But neither the Court nor the Board can amend, alter, add or delete any "uses" spelled out by Council in its land use by-law. This point is not dealt with by the Court of Appeal in this case.

It should be noted that this analysis points out the method for a City Council to precribe the specific use for a particular lot or building, and thus to eliminate completely any ability of the Development Appeal Board to permit variations from that specific use. All that the Council needs to do is to be extremely specific in articulating that use, possibly even going on to say that it includes no other uses (and possibly listing the most likely alternatives, which are not acceptable to Council). This specificity need only be contained in the land use by-law itself because the Development Appeal Board's dispensing power under paragraph 85(3)(c) is directed only to that by-law. There is no need to enact a statutory plan - and perhaps no point in light of the Court of Appeal's ruling in Bridgeland-Riverside that the Board's discretion under paragraph $85(3)$ (c) survives the enactment of such a plan.

The second complication arises if the statutory plan specifies "other" matters besides the use affecting the development of the particular land

19. With one exception: direct control districts governed by s. $\mathbf{7 0}$.

20. Nowhere in the judgment is there any detailed reference to the C2 classification. At first glance, one might assume that the $\mathrm{C} 2$ classification did not include a residential apartment building as one of its permitted or discretionary uses. The author, however, has been informed by Counsel that the reverse in fact was true, and that the $C 2$ classification permitted certain residential apartment dwellings, but at a lower density than contemplated by the proposed development. The former classification, C3, would have permitted the higher density apartment. Hence the question in the judgment whether the Area Redevelopment Plan in fact redistricted the land to C2. If it did not, the ratio of the case would be much narrower - namely, that the plan was merely defectively prepared, and the original C3 classification still governed the land in question. On the other hand, it is important to note that the land use by-law was also amended, and that the land in question was in fact changed from C3 to C2 under the by-law. The issue then is whether the lower density requirements of the C2 classification were "other" matters - as opposed to a "use" - which the Board could waive under s. 85(3)(c) of the Act.

Interestingly, the Transcript of the hearing before the Development Appeal Board indicates that at least some members voted for the relaxation of the amended land use by. law because it unfairly "down-zoned" the applicant's land. (The transcript was included in the Appeal Book, and was therefore before the Court of Appeal, although it is not referred to in their judgment). Yet. The Planning Act clearly does not give the Board any power to ignore the provisions of an Area Redevelopment Plan, nor is it the Board's concern whether such a plan is "fair". 
or building. Because paragraph 67 requires the plan to comply with the land use by-law, the latter will undoubtedly be amended to reflect these "other" aspects of the plan regulating each particular property. ${ }^{21}$ Does the Board's dispensing power under paragraph 85(3)(c) with respect to such "other" matters endure, or is it effectively sterilized by the enactment of the plan? Although the Court opted for the former interpretation, it conceded ${ }^{22}$ that both constructions were possible, and it is necessary therefore to examine whether their Lordships' reasoning accords with the policy underlying The Planning Act.

As noted above ${ }^{23}$ Kerans $\mathrm{J}$. held that the Board's dispensing powers survive the enactment of any plans, and that nothing in Part 3 of the Act (dealing with area re-development plans) authorizes a local government to sterilize the very special dispensing powers of a development appeal board to vary a land use by-law with respect to these "other" matters.

With respect, the alternative construction appears to be far more in keeping with the Legislature's intention. In the first place, paragraph 85(3)(a) requires the Board to comply with all plans. ${ }^{24}$ The Board's dispensing powers under paragraph 85(3)(c) specifically refer to land use by-laws or regulations. ${ }^{25}$ This implies a hierarchy of planning instruments, with only those at the lowest leve ${ }^{26}$ subject to the Board's dispensing power. Note that paragraph 85(3)(c) does not give the Board power to approve a development which does not comply with a statutory plan or with the land use by-law; only the latter is referred to. The effect, however, of the Court's decision in this case is to re-write the subsection in precisely this manner, contrary to the normal rules of statutory interpretation.$^{27}$ Second, even if the Court's interpretation is correct, the Board's dispensing power does not actually amend the statutory plan but merely dispenses from its operation; and it is extremely difficult to see how the Board's order can possibly therefore "comply" with the plan. Third, the Court's interpretation ignores the fact that the conformity requirements of an area redevelopment plan are bilateral because such plans must conform with all other statutory plans (higher up in the hierarchy of planning documents) as well as with the land use by-law (lower down). Has the Court effectively given the Board power to dispense with aspects of all statutory plans - viz., all general municipal plans, all area structure plans, and all area redevelopment plans? ${ }^{28}$ Surely the Legislature would have used clearer language to indicate this result. Fourth, in this author's experience, an area redevelopment plan is intended to deal very specifically with all aspects of land and buildings within its area, not just

21. Note that the Calgary Council in fact amended the land use by-law in question to reflect the plan. It therefore is difficult to argue that this particular plan did not prescribe a particular use for the property, but only constituted a mere statement of intent to alter the land use by-law.

22. Supra n. 1 at 365 . Indeed, Kerans J. specifically states that the "plain meaning" of $\mathbf{s .}$ $85(3)(c)$ favours the construction not adopted by the Court. With respect, if there is no ambiguity to these plain words, what right does the Court have to deviate from their plain meaning? What possible basis of statutory construction does the Court reply upon?

23. Supra n. 7.

24. Supra n. 3.

25. Id.

26. That is, the land use by-laws or regulations.

27. See n. 22, supra.

28. What about regional plans, or ministerial regional plans, which are not "statutory plans" within the definition contained in s. 1 (u. 1)? 
prescribing vague and general "uses". By comparison, land use by-laws are frequently extraordinarily vague and general, and each classification applies to a wide range of properties located across the municipality. The purpose of an area redevelopment plan is to provide a "statutory overlay" to the general land use by-law, to deal with specific details for that area. Such a plan is usually enacted after the most laborious consultation with the neighbourhood involved, and would be pointless if its details were at the mercy of the dispensing power of an appointed development appeal board. All of these considerations indicate, to this author at least, that the Legislature in fact used clear words to put all aspects of the plans beyond the dispensing powers of the development appeal boards, and that the Court of Appeal has erred in its construction of the Act. Perhaps a legislative amendment will clarify this point.

One final point can be made on this part of the judgment. At the beginning ${ }^{29}$ Kerans J. states that the question is whether the Board failed to "comply" with the Plan. He goes on to canvas whether the Plan in fact prescribes specific uses for the land in question, or merely constitutes a statement of intent by Council to change the uses contained in the land use by-law to reflect the Plan. If the latter were the case, then the Plan could not possibly vary from the by-law, and there would be no question of the Board's power to dispense with the "other" requirements of the bylaw. Indeed, this case would merely be an example of a defective or ineffective Plan; and it would not raise any of the issues decided by the Court and discussed above.

In light of His Lordship's holding that only the land use by-law matters, because it is the context within which the Board's dispensing power under paragraph $85(3)(c)$ operates, it was not in the end necessary to decide exactly what the Plan did. And, because the by-law was in fact amended to reflect the Plan, no contradiction between the two could arise.

The moral is that a municipal council must amend its land use by-law simultaneously with the adoption of a statutory plan; the latter alone may well be ineffective. One might query what would be the consequence of a failure to do so, who (if anyone) would have standing to complain, whether the council could be compelled to amend the land use by-law to implement the plan, and whether damages would arise if such amendments were not made after a plan had been adopted.

\section{VOID OR VOIDABLE, AND DOES IT MATTER?}

The second part of Kerans J.'s judgment considers whether the Board's decision was void or merely voidable as a result of its failure to readvertize and give new notice to interested parties after the applicant's amendment to its proposed development.

Section 84(3)(d) of The Planning Act ${ }^{30}$ specifically requires the Board to give at least 5 days' notice in writing of the public hearing of the appeal to the Board:

(d) to those owners required to be notified under the land use by-law and any other persons that the development appeal board considers to be affected by the appeal and should be notified.

Notice of the original application appears to have been given correctly. However, no further notice was given concerning the amended applica-

29. Supra n. 1 at 365 .

30. Formerly s. 82(3)(d). 
tion which we are told proposed a different building design and included additional lands. Only the intervenors (including the Bridgeland Riverside Community Association) were notified of the proposals, ${ }^{31}$ not all of those enumerated in s. 84(3)(d). The question arose as to the legal consequence of this procedural irregularity, which Kerans J. put this way: ${ }^{32}$

On the one hand, it can be argued that the Board should be held, without exception, to its clear statutory duty to give due notice to all persons. On the other hand, it can be argued that procedural requirements should always be subordinate to substantial issues, and if there is no possible prejudicial effect on a substantial issue, no effect should be given to any procedural default.

After referring to selected earlier cases on this point - drawn indiscriminately from the contexts of statutory appeals, declarations and the prerogative remedies, which may have different rules - His Lordship said: ${ }^{3}$

In my view, no concept is more sterile than that which says that a proceeding is a nullity for failure of compliance with a procedural rule and without regard to the effect of the failure.

In the present case, the Appellant community association did have actual notice of the amendments which the developer made before the Board, and it is not surprising that Kerans J. dismissed this ground for the Association's attack on the Board's decision. His Lordship, however, did so in very broad terms: ${ }^{34}$

In my view, absent an express statutory statement of effect, no defect should vitiate a proceeding unless, as a result of it, some real possibility of prejudice to the attacking party is shown, or unless the procedure was so dramatically devoid to the appearance of fairness that the administration of justice is brought into disrepute.

Finally, His Lordship noted that other persons, not notified of the amendment, might well successfully attack the Board's decision: ${ }^{35}$

I hasten to add that denial of this appeal would do no injustice to those unnamed, unnotified, persons not before us. They could have attacked the decision of the Board successfully by prerogative writ [sic], if not statutory appeal, provided that they were not guilty of unreasonable delay.

What can one say of this analysis?

First, it is important to note that the Court of Appeal did not clearly state that it was considering a statutory appeal, and not an application for a declaration or for one of the prerogative remedies. With respect, the rules respecting the refusal of a statutory appeal may well differ from the discretion of the court to refuse judicial review of administrative action. It is disconcerting, therefore, to realize that Kerans J. relies on six cases ${ }^{36}$ drawn indiscriminantely from these two lines of authorities.

Second, His Lordship did not refer to the most recent authorities on the void/voidable point in administrative law. Although he referred to Ridge v. Baldwin, ${ }^{37}$ Durayappah v. Fernando, ${ }^{38}$ and Wiswell ${ }^{39}$ no mention is

31. Quaere: at the hearing? in writing?

32. Supra n. 1 at 367.

33. Id. at 368. Emphasis added

34. Id. Emphasis added

35. Id. Note that we do not have prerogative writs in Alberta, but rather prerogative orders, with somewhat different procedures.

36. The cases are: Children's Aid Society of Metropolitan Toronto v. Lyttle (1973) 34 D.L.R. (3d) 127 (S.C.C.); Ridge v. Baldwin [1964] A.C. 40(H.L.);Durayappah v.Fernando [1967]2 A.C. 337 (P.C.): Wiswell v. Metropolitan Corporation of Greater Winnipeg [1965] S.C.R. 512 (S.C.C.); Fontaine v. Serben and Serben [1974] 5 W.W.R. 428 (Alta. D.C.); Rizzie v. J.H. Lilley and A ssociates Ltd. [1976] 2 W.W.R. 97.

37. Id.

38. Id.

39. Id. 
made of Anisminic, ${ }^{40}$ Harelkin $^{41}$ or the lengthy academic discussions of this point. ${ }^{42}$

Third, the Court makes no reference at all to the public law rationale which is of the highest constitutional importance - for the rule that a breach of the principles of natural justice is an excess of jurisdiction, and renders the decision void. To say that such a decision is voidable is extremely dangerous because it would be protected from judicial review by a privative clause, no matter how great the injustice or how eagerly the Court wished to intervene. Sterile or not, the distinction between void and voidable in administrative decisions is critical to all of the theory and practice of administrative law. If the attacking party is not prejudiced by the void decision, the Court - in administrative law, at least - can always exercise its discretion to refuse the remedy sought, ${ }^{43}$ or perhaps carefully scrutinize the applicant's standing to seek that remedy.4

Fourth, the Court appears to act on the assumption that lack of notice is merely procedural, and therefore somehow unimportant. In fact, the principles of natural justice (or procedural fairness) apply to all delegates of statutory powers, and the non-observance of these procedures ranks as a substantive defect to the delegate's jurisdiction every bit as much as any other form of substantive ultra vires. ${ }^{45}$ The common law imposes the procedural requirements on the statutory delegate and no specific legislation is required to impose such a procedural fairness. It seems odd in this case that the Applicant apparently is worse off merely because the Legislature specifically required its delegate to give notice in writing in advance to the persons enumerated in S. 84(3)(d) of The Planning Act. ${ }^{46}$ With respect, it seems perverse for the Court to hold that a breach of natural justice should be excused unless there is "an express statutory statement of the effect" of a breach of the statutory requirement to give notice.

Fifth, the statutory scheme of The Planning Act provides an ideal mechanism to avoid the multiplication of actions, which Kerans J. appears to contemplate when he refers to the possibility of another person, who had not received notice, successfully bringing an appeal or application for a prerogative remedy ${ }^{47}$ against the Board. Section 152 of the Act ${ }^{48}$ creates a two-step procedure for appealing a decision of a development appeal board ${ }^{49}$ to the Court of Appeal. First, leave to appeal must be sought on a point of law or jurisdiction, and only if leave is granted does the appeal proceed on to a three-man panel of the Court. Section 152(2) specifically

40. [1969] 2 W.L.R. 163 (H.L.).

41. [1979] 2 S.C.R. 561.

42. See H.W.R. Wade, "Unlawful Administrative Action: Void or Voidable?", Part I at (1967) 83 L.Q. Rev. 499, Part II at (1968) 84 L.Q. Rev. 95; H.W.R. Wade, Administrative Law (4th ed., 1977) 296-301 and 447-450. See also D.P. Jones, "Discretionary Refusal of Judicial Review in Administrative Law" (1981) 19 Alta. L. Rev. 483.

43. Though Kerans $J$. is extremely critical of the Court's exercise of their discretion to refuse judicial review. See the Hoyda case, infra n. 51.

44. Indeed, the Durayappah decision may well be explained as a case dealing with standing. not voidability.

45. Otherwise, the leading decision in Cooper v. Wandsworth Board of Works (1863) 14 C.B. (N.S.) 180, 143 E.R. 414, would have been different.

46. Formerly s. 82(3)(d).

47. See n. 35, supra.

48. Formerly s. 150.

49. Or the Provincial Planning Board, as the case may be. 
requires notice of the leave application to be given to the board ${ }^{50}$ the $\mathrm{mu}$ nicipality, and to "such other persons as the judge may direct". Surely, the leave application should have been drawn to the attention of all of the persons entitled to notice of the original development application to the board under s. $84(3)(\mathrm{d})$ of the Act. This is particularly true now that the notice of motion applying for leave is required under the Rules of Court to set out the specific grounds for seeking leave. Accordingly, the Court at that stage ought to have been in a position to realize that a procedural argument was being raised and that those affected by the defect should be given an opportunity to be present. At any rate, an adjournment could have been granted to permit such notice to be given of the leave application. Alternatively, section $152(3)(b)$ permits the judge to "direct which persons and other bodies shall be named as respondents to the appeal" when granting leave, and this could be used to protect the developer from a subsequent challenge to the Board's decision by a person to whom the Board did not give notice of the amended application.

Sixth, one must regret that the Court of Appeal did not even canvas what types of amendments to a development application require renotification of the neighbouring property owners enumerated in section $84(3)(d)$. Must every amendment be re-notified, or only those which substantially alter the project as advertised (e.g., requiring the ground floor of a proposed six-story apartment to be commerciall? Surely, renotification must be done at least whenever a reasonable person, otherwise entitled to notice, might choose to make representations about the changes, even though not doing so with respect to the original proposal. In any event, the decision in Bridgeland-Riverview cannot be taken as any general authority exempting a Board from re-notification of any amendments to an application.

Finally, it is unfortunate that Kerans J. did not even refer to the earlier Court of A ppeal decision in $E$ dith Lake Service L td. and Hoyda Holdings $L t d$. v. The City of Edmonton, ${ }^{51}$ which clearly holds that the courts should exercise their discretion to refuse a prerogative remedy whenever an appeal could be taken - on whatever issue - to the Development Appeal Board.

In summary, one must approach the Court's decision in this case with considerable caution, and with considerable regret that the issues raised in this comment were not fully dealt with by the three members of the Court.

50. Id.

51. Unreported, December 1981, Judicial District of Edmonton, No. 14105, per Haddad J.A., (Lieberman J.A. concurring), Kerans J.A. dissenting. 